\title{
THE IMPACT OF AUTHENTIC LEADERSHIP ON ORGANIZATIONAL LEARNING CAPACITY
}

\author{
*Senol OKMEN \\ *Meral ELCI \\ *Gulay MURAT \\ *Yusuf YILMAZ \\ *Gebze Technical University, Turkey
}

\begin{abstract}
Authentic leaders' impact on organizational learning capacity has rarely been addressed in leadership context. We concentrated on the concept of leadership style affect leaders' followers and firm. In this study, we empirically examined how authentic leadership has an effect on organizational learning capacity which has dimensions of system orientation, climate for learning orientation, knowledge acquisition, and utilization orientation, and information sharing and dissemination orientation. A survey is conducted with 235 administrators, academic members, prelectors, teachers and administrative staff working in Kocaeli and Istanbul schools and universities. The acquired data are analyzed with SPSS software to perform regression analyses. As a result, it revealed that authentic leadership behaviors have positive impact on the knowledge acquisition and utilization orientation, and information sharing and dissemination orientation. It also has partially positive impact on systems orientation and climate for learning orientation. Our findings are in line with leadership and organizational learning literature.
\end{abstract}

Keywords: Leadership styles; Authentic leadership; Organizational learning; Organizational learning capacity

\section{INTRODUCTION}

Leadership is a concept that has been subject to research for centuries. It is highly important for organizations to achieve their corporate objectives in continuous changing conditions the competition has created. Organizations should realize this change in accordance with the expectations of employees and customers. The expectation of change is an important factor in increasing the interest in leadership. People can not do various work alone. It is necessary for people to cooperate with each other in order to achieve their goals and be successful and effective. Nowadays, administrators use their powers only on the basis of legal authority. However, there is a strong need for leaders who are able to cooperate in their business environment, making their employees work with self-sacrifice and directing effectively achieve the organization's goals in our globalized world. Therefore, it is necessary to focus on positive leadership approaches and authentic leadership development which is another branch of positive leadership (Avolio and Gardner, 2005). Keeping up the pace with technology, taking the pulse of customers and employees requires knowledge and information. Information leads to learning. Organizational learning the process by which organizations learn- evaluated by academics and executives as fundamental for organizations mostly because of the fastmoving environment. As a result, organizational learning capacity, expressed as organisational and managerial characteristics that enable the learning process or an organization to learn, acts as vital part (Chiva et al, 2007). Firms need to improve their organizational learning capacity to be more effective and competitive. This study is intended to examine the effect of authentic leadership on organizational learning capacity.

\section{THEORETICAL FRAMEWORK Authentic Leadership}

The concept of authentic leadership has been discussed and explored since the early 1990s. In order to be able to explain authentic leadership, we first have to define authenticity. Authenticity expresses original, authentic, correct, reliable, original meanings that are real, based on fact or originality. The Anatolian philosopher Rumi also refers to authenticity in his expression: "Either seem as you are or be as you seem". Authenticity does not mean satisfying others, helping people to get rewards or preventing 
punishment. On the contrary, authentic behavior involves one's own and others acting in harmony with their values, preferences, and needs (Kernis, 2003).

Authenticity is knowing one's own identity. There is a need for leaders who know themselves, build their self correctly and properly. Authentic leadership is a process which depicts both positive psychological capacity and advanced organizational context. It defines the individuals supporting the development of the leader and it's consequential, these individuals are also aware of the potentials and question themselves (Luthans and Avolio, 2003). Luthans and Avolio initially defined "authentic leadership as a process that draws from both positive psychological capacities and a highly developed organizational context, which results in both greater self-awareness and self-regulated positive behaviors on the part of leaders and associates, fostering positive self-development" (Walumbwa et al., 2008).

According to the findings and recommendations of Hannah et al., The authentic leader must also include (2005): a) Promising and providing confidence to people around himself, his audience, family, customers, and society, b) having a high degree of power stemming from his character, c) increasing social identification with the leader and emulation of his or her moral actions and d)the followers being aware of the leader's moral potentials.

Regarding authentic leadership; there are 4 dimensions that researchers emphasize. These are, selfawareness; one's self-recognition and aware of thoughts, feelings, actions, and behaviors (Illies et al., 2005), balanced processing; evaluating the relevant information objectively, internalized moral perspective; an internalized and integrated form of self-regulation (Walumbwa et al., 2008) and altruistic, virtuous leader behavior, relational transparency; refers to be clear and openness.

\section{Organizational Learning Capacity}

The ability of organizations to produce and innovate certainly can be achieved with organizational learning. Organizational learning capacity makes the learning process possible in organizations. Organizational learning capacity is expressed as administrative and organizational characteristics which make the learning process possible and transforms an organization into a learning organization (Emhan et al., 2015). Learning capacity is a key factor for learning organizations. It has a significant influence on growth, innovation and organizational effectiveness. It is assessed that an organization can become a learning organization by increasing its organizational learning capacity (Aydoğan et al., 2011).

Chiva and Alegre (2008) consider organizational learning capacity as a requirement for an organizational's effectiveness and adaptation to a rapidly changing environment. They also view organizational learning capacity as a potential for development and innovation. Schein (1999) stated that knowing and developing organizational learning capacity is based on four factors. These factors are: (i) creation of identity, purpose and mission awareness, (ii) monitoring internal and external changes / developments and ensuring harmony, keeping track of developments and ensuring harmony, (iii) testing and analyzing the effects of the developments on the organization, (iv) ensuring the integrity and solidarity between the subsystems (Teo et al., 2006).

Teo et al. also searched for ways to improve organizational learning capacity in their research and examined them in four dimensions. These dimensions, we use in our work to measure organizational learning capacity are systems orientation that may be defined as seeing the big picture; climate for learning orientation that is a measure encourages the learning in the organization (Marquardt, 1996); knowledge acquisition and utilization orientation that is an ability about innovativeness, technology and continuous improvement; information sharing and dissemination orientation that is defined as the degree of reaching the knowledge in the organization (Hult and Ferrel, 1997).

\section{HYPOTHESIS DEVELOPMENT}

Although we did not see a direct research between authentic leadership and organizational learning capacity. some of studies in this field give us a bit of subject matter. For example, Elkins and Keller (2003) argue that organizational learning is increasing steadily with effective leadership. Vera and Crossan (2004) point out that the strategic leadership perspective influences organizational learning practices. In another study, Bocernea et al. (2015) tried to explore the effect of authentic leadership and organizational learning capacity on innovative behavior. Authentic leadership and organizational learning capacity promote innovative behavior. According to a research conducted by local governments. 
Journal of Global Strategic Management | V. 12 | N. 1 | 2018-June | isma.info | 057-066 | DOI: 10.20460/JGSM.2018.261

The following hypotheses are proposed for testing:

$H_{1}$ : Authentic leadership positively influences system orientation.

$\mathrm{H}_{2}$ : Authentic leadership positively influences climate for learning orientation.

$\mathrm{H}_{3}$ : Authentic leadership positively influences knowledge acquisition and utilization orientation.

$H_{4}$ : Authentic leadership positively influences information sharing and dissemination orientation.

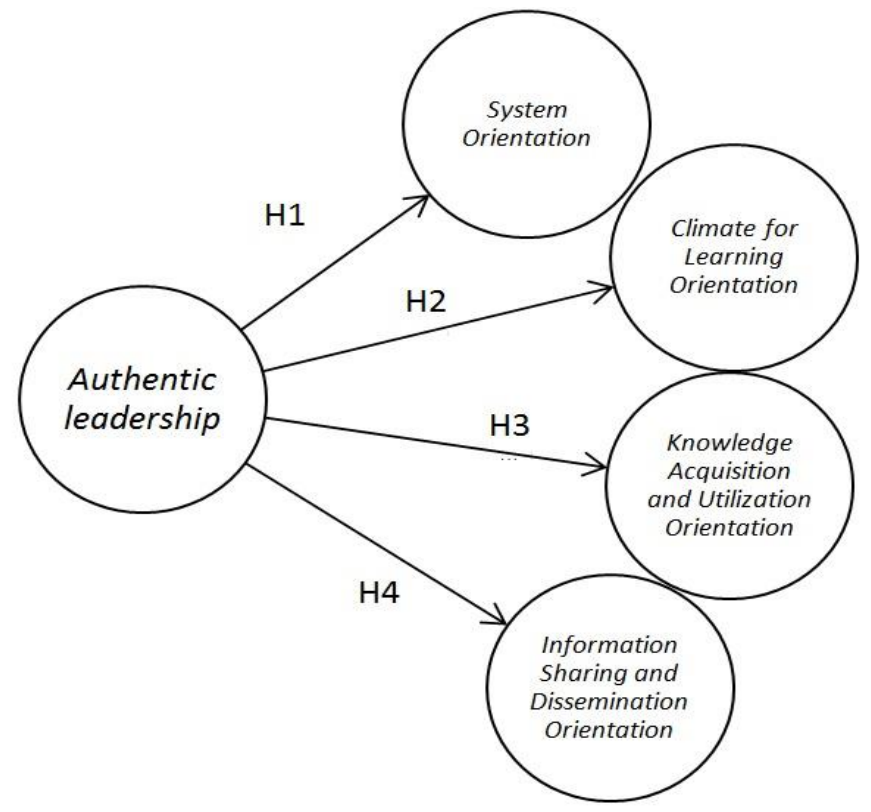

Figure 1: Research Model

\section{RESEARCH METHOD Sample and Data Collection}

The study was conducted in Turkey. The data were collected from 235 employees from public and private universities and schools in İstanbul and Kocaeli cities via survey method. Participants were academic members, prelectors, teachers and administrative staff. We did not determine any criteria regarding private or public schools or regarding primary education or higher as we acknowledge education as a whole system. The data obtained from surveys were analyzed with SPSS software program and hypotheses tested.

\section{Analyses}

In the study authentic leadership was measured using the 16-item AL Questionnaire of Walumbwa et al. (2008). These scales translated and adapted in Turkish by Booms (2009) and Tabak et al. (2010). Organizational learning capacity was measured using the 21-item OLC Questionnaire of Teo et al. (2006), as this scales translated and adapted in Turkish by Aydın (2009) and Çelik (2014).

KMO values for authentic leadership and organizational learning capacity scales are respectively .901 and .922. The exploratory factor analysis for authentic leadership and organizational learning capacity displayed each scale having a four-factor structure as expected. After eliminating two items which indicating weak loading, thirty-five items which uses 5 Likert type scales have used to measure authentic leadership and organizational learning capacity.

The factor analyses performed upon variables related with authentic leadership and organizational learning capacity displayed a strong factor structure. This analysis indicates that the expressions on the scale are sufficiently suitable for factor analysis. The factor loadings for each scale are displayed in Table 1. 
Journal of Global Strategic Management | V. 12 | N. 1 | 2018-June | isma.info | 057-066 | DOI: 10.20460/JGSM.2018.261

Table 1. Factor Analysis Results for Authentic Leadership and Organizational Learning Capacity

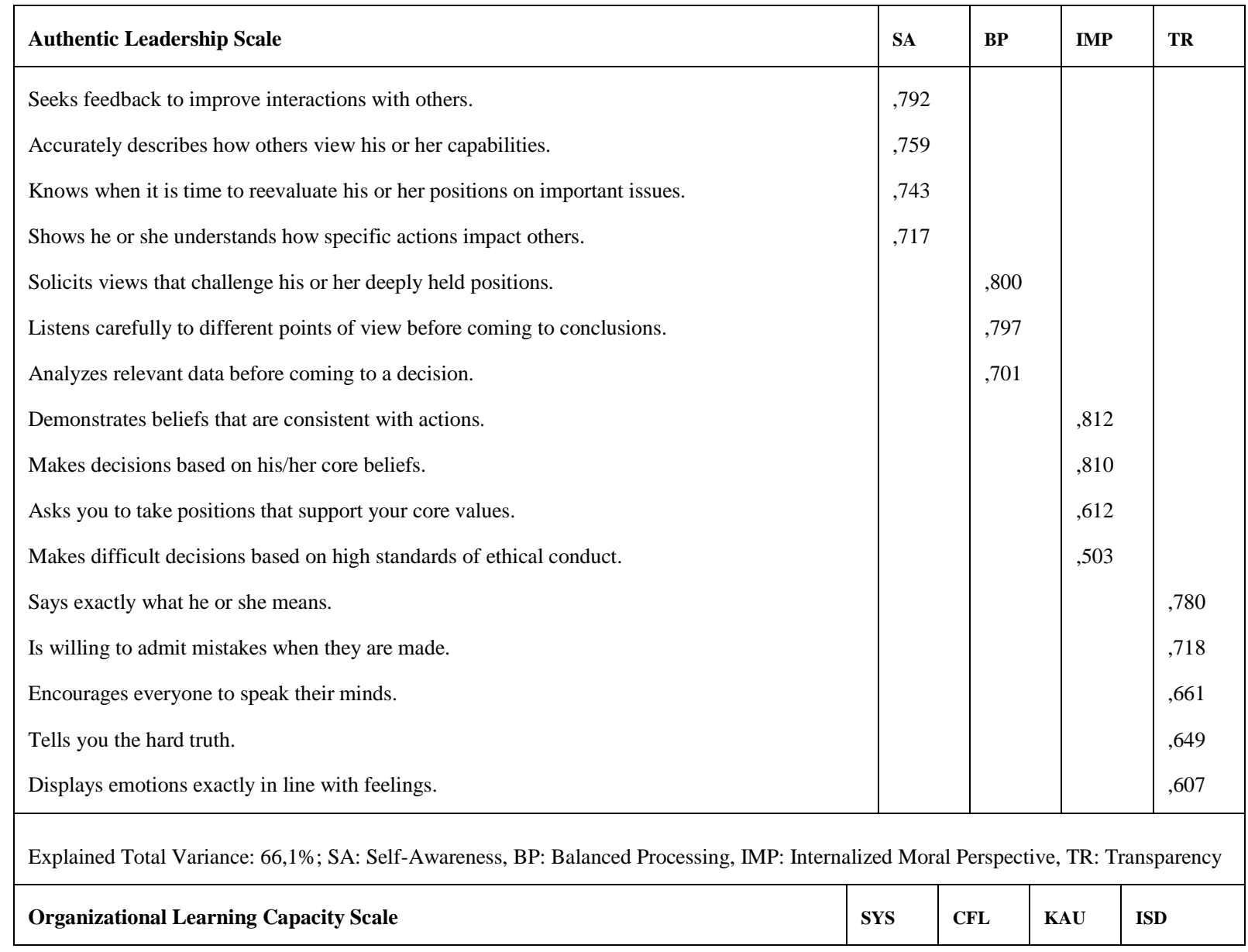


My staff have a good sense of my firm's business processes as a whole and the interconnectedness of all components of these processes.

All activities that take place in business transaction processes are clearly defined.

All parts of each business process are dependent to form a value chain.

We basically agree that our ability to learn is the key to the improvement of our firm.

Our basic values of any change in the business process include learning as a key to improvement.

It is my firm's policy to encourage staff to have continuous education.

The sense around here is that employee learning is an investment, not an expense.

Learning in my firm is seen as a key to guarantee the firm's existence in its sector.

It is necessary to attempt to develop new ways of looking at my firm's business processes regularly.

My firm regularly does research on the trend in technology pertinent to the way our business operates.

My firm regularly assesses the potential influence of new technology on its operations.

My firm is susceptible to new technology and/or method to do business.

My firm has specific mechanisms to do environmental scanning on technology.

My firm is quick to detect a change in the methods/technology employed by other firms in this sector.

Pertaining to technological issues, when a staff finds out something of importance to my firm, he or she is quick to alert others.

Pertaining to technological issues, my staff is willing to influence me with his or her information to let me make a better decision.

Pertaining to technological issues, it is my firm's policy that valuable insights or methods should be shared and used across the organization.

Pertaining to technological issues, there is a good deal of organizational conversation, which keeps alive the lessons learned from history.

Pertaining to technological issues, my firm has specific mechanisms for sharing knowledge, which can enhance the firm's competitiveness.

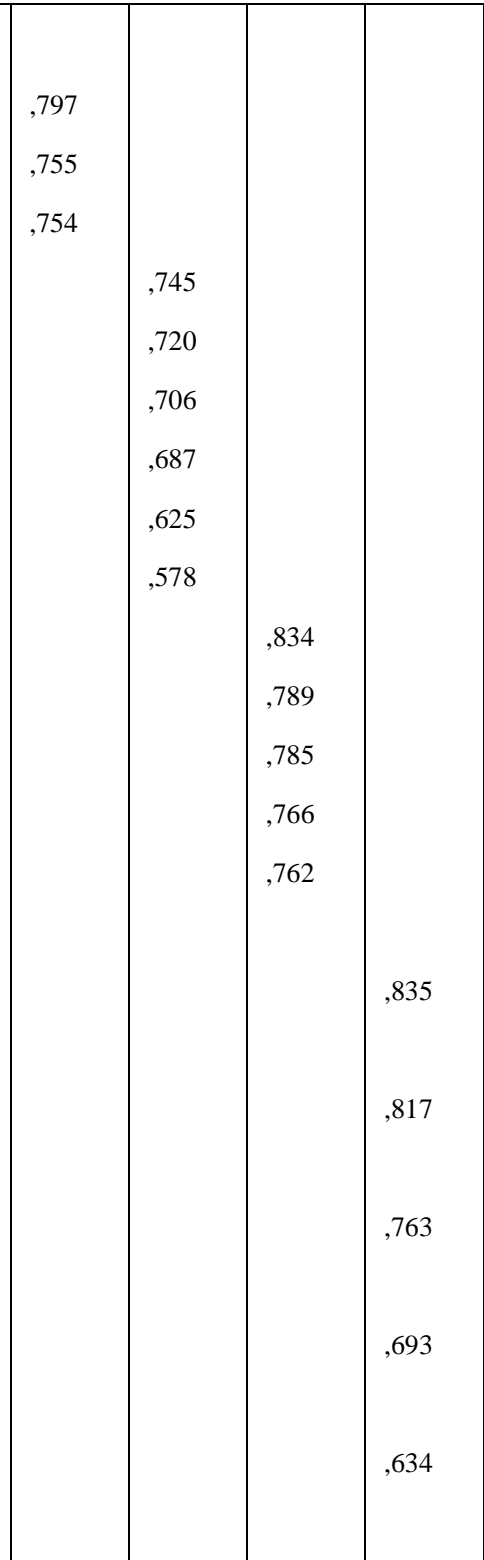

Explained Total Variance: 69,6\%; SYS: System Orientation, CFL: Climate For Learning, KAU: Knowledge Acquisition And Utilization, ISD: Information Sharing And Dissemination.

Table 2 demonstrates the reliabilities, mean, standard deviations and correlations for the variables in this study. Hence, as it can be seen along the diagonal of the correlation matrix, each scale has satisfactory reliability with The Cronbach's Alpha values for each factor exceeds 0,70 . 
Journal of Global Strategic Management | V. 12 | N. 1 | 2018-June | isma.info | 057-066 | DOI: 10.20460/JGSM.2018.261

Table 2. Correlations, Mean, Standard Deviations and Alpha Reliabilities

\begin{tabular}{|l|l|l|l|l|l|l|l|l|l|l|}
\hline Variable & Mean & SD & $\begin{array}{c}\text { Cronba } \\
\text { ch }(\boldsymbol{\alpha})\end{array}$ & SA & BP & IMP & TR & SYS & CFL & KAU \\
\hline SA & 3,6182 &, 80984 &, 836 & 1 & & & & & & \\
\hline BP & 3,5591 &, 93913 &, 794 &, $556^{* *}$ & 1 & & & & & \\
\hline IMP & 3,5402 &, 74278 &, 779 &, $494^{* *}$ &, $450^{* *}$ & 1 & & & & \\
\hline TR & 3,5634 &, 84255 &, 841 &, $553^{* *}$ &, $586^{* *}$ &, $613^{* *}$ & 1 & & & \\
\hline SYS & 3,5014 &, 88176 &, 841 &, $358^{* *}$ &, $382^{* *}$ &, $426^{* *}$ &, $474^{* *}$ & 1 & & \\
\hline CFL & 3,8242 &, 75001 &, 846 &, $302^{* *}$ &, $397^{* *}$ &, $460^{* *}$ &, $429^{* *}$ &, $576^{* *}$ & 1 & \\
\hline KAU & 3,4053 &, 90561 &, 917 &, $379^{* *}$ &, $339^{* *}$ &, $460^{* *}$ &, $460^{* *}$ &, $557^{* *}$ &, $576^{* *}$ & 1 \\
\hline ISD & 3,5124 &, 86390 &, 890 &, $379^{* *}$ &, $363^{* *}$ &, $359^{* *}$ &, $391^{* *}$ &, $544^{* *}$ &, $533^{* *}$ &, $604^{* *}$ \\
\hline
\end{tabular}

\section{Findings}

A regression analysis was applied to investigate the effects of the authentic leadership on organizational learning capacity. Self-awareness, balanced processing, internalized moral perspective, transparency are independent variables. System orientation, climate for learning, knowledge acquisition and utilization, information sharing and dissemination are dependent variables. The results of regression analysis were examined.

\section{The Impact of Authentic Leadership Dimensions on System Orientation}

Table 3 shows the results of regression analysis between authentic leadership dimensions and system orientation. The model is significant as a whole (Adjusted $\mathrm{R}^{2}=, 254 ; \mathrm{F}=20,957 ; \mathrm{Sig}=, 000$ ). According to the results of this analysis, it was found out that system orientation was affected by internalized moral perspective $(\beta=, 185 ; \mathrm{p}$ value $=, 013)$ and transparency $\left(\beta=, 263\right.$; $\mathrm{p}$ value=,001). Hence, $\mathrm{H}_{1}$ was partially supported.

Table 3. The Effects of Authentic Leadership Dimensions on System Orientation

\begin{tabular}{|c|c|c|c|}
\hline Model 1 & \multirow{2}{*}{ Std. Coef. Beta } & $\mathrm{t}$ & Sig. \\
\cline { 1 - 2 } $\begin{array}{c}\text { Dependent Variable: } \\
\text { System Orientation }\end{array}$ &, 060 &, 814 &, 417 \\
\hline Self-Awareness &, 111 & 1,494 &, 136 \\
\hline Balanced Processing & $\mathbf{1 8 5}$ & $\mathbf{2 , 5 1 2}$ & $\mathbf{, 0 1 3} *$ \\
\hline Internalized Moral Perspective & $\mathbf{2 6 3}$ & $\mathbf{3 , 2 2 4}$ & $\mathbf{, 0 0 1} * *$ \\
\hline Transparency & $\mathrm{F}=20,957$ & Sig. $=, 000$ \\
\hline $\mathrm{R}^{2}=, 254$ & \multicolumn{3}{|c}{} \\
\hline
\end{tabular}

$* * \mathrm{p}<0,01 ; * \mathrm{p}<0,05$ 


\section{The Impact of Authentic Leadership Dimensions on Climate For Learning}

Table 4 shows the results of regression analysis between authentic leadership dimensions and climate for learning. The model is significant as a whole (Adjusted $\mathrm{R}^{2}=, 256 ; \mathrm{F}=21,110 ; \mathrm{Sig}=, 000$ ). According to the results of this analysis, it was found out that climate for learning was affected by balanced processing $(\beta=, 194 ; \mathrm{p}$ value $=, 010)$, internalized moral perspective $(\beta=, 297 ; \mathrm{p}$ value $=, 000)$ and transparency $(\beta=, 154$; $\mathrm{p}$ value $=, 029$ ). Hence, $\mathrm{H}_{2}$ was supported.

Table 4. The Effects of Authentic Leadership Dimensions on Climate For Learning

\begin{tabular}{|c|c|c|c|}
\hline \multirow{2}{*}{ Model 2 } & \multirow{2}{*}{ Std. Coef. Beta } & $\mathrm{t}$ & Sig. \\
\cline { 1 - 2 } $\begin{array}{c}\text { Dependent Variable: } \\
\text { Climate For Learning }\end{array}$ &,- 038 &,- 516 &, 607 \\
\hline Self-Awareness & $\mathbf{1 9 4}$ & $\mathbf{2 , 6 1 4}$ & $\mathbf{, 0 1 0} *$ \\
\hline Balanced Processing & $\mathbf{2 9 7}$ & $\mathbf{4 , 0 3 7}$ & $\mathbf{, 0 0 0} * *$ \\
\hline Internalized Moral Perspective & $\mathbf{1 5 4}$ & $\mathbf{1 , 8 9 5}$ & $\mathbf{, 0 2 9} *$ \\
\hline Transparency & $\mathrm{F}=21,110$ & Sig.=,000 \\
\hline $\mathrm{R}^{2}=, 256$ & \multicolumn{3}{|c}{} \\
\hline
\end{tabular}

$* * \mathrm{p}<0,01 ; * \mathrm{p}<0,05$

\section{The Impact of Authentic Leadership Dimensions on Knowledge Acquisition and Utilization}

Table 5 shows the results of regression analysis between authentic leadership dimensions and knowledge acquisition and utilization. The model is significant as a whole (Adjusted $\mathrm{R}^{2}=, 260 ; \mathrm{F}=21,556 ; \mathrm{Sig}=, 000$ ). According to the results of this analysis, it was found out that knowledge acquisition and utilization was affected by internalized moral perspective $(\beta=, 252, \mathrm{p}$ value $=, 001)$ and transparency $(\beta=, 226 ; \mathrm{p}$ value $=, 006)$. Hence, $\mathrm{H}_{3}$ was partially supported.

\section{Table 5. The Effects of Authentic Leadership Dimensions on Knowledge} Acquisition and Utilization

\begin{tabular}{|c|c|c|c|}
\hline Model 3 & Std. Coef. Beta & $\mathrm{t}$ & Sig. \\
\cline { 1 - 4 } $\begin{array}{c}\text { Dependent Variable: } \\
\text { Knowledge Acq. and Utl. }\end{array}$ &, 112 & 1,525 &, 129 \\
\hline Self-Awareness &, 031 &, 422 &, 673 \\
\hline Balanced Processing & $\mathbf{2 5 2}$ & $\mathbf{3 , 4 3 0}$ & $\mathbf{0 0 1 * *}$ \\
\hline Internalized Moral Perspective & $\mathbf{, 2 2 6}$ & $\mathbf{2 , 7 8 5}$ & $\mathbf{0 0 6 * *}$ \\
\hline Transparency & $\mathrm{F}=21,556$ & Sig. $=, 000$ \\
\hline $\mathrm{R}^{2}=, 260$ & \multicolumn{4}{|l}{} \\
\hline
\end{tabular}

$* * \mathrm{p}<0,01$

\section{The Impact of Authentic Leadership Dimensions on Information Sharing and Dissemination}

Table 6 shows the results of regression analysis between authentic leadership dimensions and information sharing and dissemination. The model is significant as a whole (Adjusted $\mathrm{R}^{2}=, 199 ; \mathrm{F}=15,505 ; \mathrm{Sig}=, 000$ ). According to the results of this analysis, it was found out that climate for learning was affected by self- 

awareness $(\beta=, 162, p$ value $=, 017)$, balanced processing $(\beta=, 128 ; p$ value $=, 049)$, internalized moral perspective $(\beta=, 132 ; \mathrm{p}$ value $=, 042)$ and transparency $(\beta=, 145 ; \mathrm{p}$ value $=, 043)$. Hence, $\mathrm{H}_{4}$ was supported.

Table 6. The Effects of Authentic Leadership Dimensions on Information Sharing and Dissemination

\begin{tabular}{|c|c|c|c|}
\hline Model 4 & \multirow{2}{*}{$\begin{array}{c}\text { Std. Coef. Beta } \\
\text { Dependent Variable: } \\
\text { Information Sharing and Diss. }\end{array}$} & $\mathrm{t}$ & Sig. \\
\hline Self-Awareness & $\mathbf{1 6 2}$ & $\mathbf{2 , 1 2 2}$ & $\mathbf{, 0 1 7 *}$ \\
\hline Balanced Processing & $\mathbf{, 1 2 8}$ & $\mathbf{1 , 6 6 4}$ & $\mathbf{0 4 9 *}$ \\
\hline Internalized Moral Perspective & $\mathbf{, 1 3 2}$ & $\mathbf{1 , 7 3 4}$ & $\mathbf{0 4 2 *}$ \\
\hline Transparency & $\mathbf{, 1 4 5}$ & $\mathbf{1 , 7 2 2}$ & $\mathbf{0 4 3} *$ \\
\hline $\mathrm{R}^{2}=, 199$ & $\mathrm{~F}=15,505$ & Sig.=,000 \\
\hline
\end{tabular}

*p $<0,05$

\section{CONCLUSION AND DISCUSSIONS}

In this study, we aimed to find out how authentic leadership affects organizational learning capacity. The regression models resulted in important findings which have been constructed to test the hypotheses.

The results of this research are consistent with the literature, which supports that both spiritual leadership and transformational leadership are related positively to organizational learning capacity. Previous researches, it has been revealed that spiritual leadership style and transformational leadership, influence organizational learning capacity (Aydın and Ceylan, 2009; Çelik, 2014).

It is observed that the authentic leadership has a stronger level of explaining the dimensions of organizational learning capacity. When each dimension is examined separately, the self-awareness dimension has affected only the information sharing and dissemination. Balanced processing has affected the climate for learning and information sharing and dissemination. Internalized moral perspective and transparency dimensions have affected system orientation, climate for learning, knowledge acquisition and utilization, information sharing and dissemination. Thereby, it is observed that the internalized moral perspective and transparency have affected all dimensions of organizational learning capacity.

In similar studies (Wong and Cummings, 2009; Hassan and Ahmed, 2011) stated that internalized moral understanding and transparency dimensions provide a secure working environment for organizations, which in turn resulted in a healthy business outcome. Hannah et al. (2005) also supported that morality has an effect on learning, Gardner et al. (2005) and Illies et al. (2005) referred to the facilitating effect of transparency on learning. The employees' sense of their leaders and managers' morality and transparency are the most important factors affecting the organizational learning capacity.

All these studies support this study. And this study showed that organizations need to adopt fair and consistent policies that give more confidence to society. It will be appropriate to give importance to ethical, transparent, objective and leaders having a high sense of self-awareness. Employment of more authentic leaders in their organizations or, behavioral development programs in this context by organizations will provide great benefits in terms of social and institutional interests. Thus, organizations will reach both their aims and their respectable position.

Leaders expected to solve managerial problems without damaging organizational performance by the means of their leadership characteristics. Keeping a high communication and sharing information with followers encourage the learning and improve the performance of organization (Macneil, 2001) . Authentic leaders catalyse the followers growth by providing organizational learning, self determination and job satisfaction.

We expect that this study will be useful at eliminating deficiencies in the literature and be a guide to the researchers. Despite all the work done, the link between authentic leadership and organizational learning still needs to be further analyzed. 


\section{Journal of Global Strategic Management | V. 12 | N. 1 | 2018-June | isma.info | 057-066 | DOI: 10.20460/JGSM.2018.261 REFERENCES}

Alegre, J., \& Chiva, R. (2008). Assessing the impact of organizational learning capability on product innovation performance: An empirical test. Technovation, 28(6), 315-326.

Avolio, B. J., \& Gardner, W. L. (2005). Authentic leadership development: Getting to the root of positive forms of leadership. The leadership quarterly, 16(3), 315-338.

Aydin, B., Ceylan, A., (2009), The Effect of Spiritual Leadership on Organizational Learning Capacity, African Journal of Business Management, 3(5), 184-190.

Aydoğan, E., Orhan, F., Naldöken, Ü., Beylik, U., Aksay, K., (2011), Sağlık Kurumlarında Örgütsel Öğrenme Kapasitesi: Bir Kamu Hastanesi Örneği, C.Ü. İktisadi ve İdari Bilimler Dergisi, 12 (2), 191213.

Çelik, V., (2014), Örgütsel Öğrenme Kapasitesi, Yenilik ve Finansal Performans İlişkisi: Dönüşümcü Liderliğin Ilımlaştırıcı Etkisi, Yayınlanmamış Doktora Tezi, Gebze Yüksek Teknoloji Enstitüsü Sosyal Bilimler Enstitüsü, Gebze.

Chiva, R., Alegre J., Lapiedra R., (2007), Measuring organisational learning capability among the workforce, International Journal of Manpower, Vol. 28 Issue: 3/4, pp.224-242.

Elkins, T., \& Keller, R. T. (2003). Leadership in research and development organizations: A literature review and conceptual framework. The Leadership Quarterly, 14(4-5), 587-606.

Emhan, A., Cura, F., Zincirkıran, M., (2015), İş Memnuniyeti ve Öğrenme Kapasitesinin Örgütsel Performans Üzerindeki Etkisi: Bankacılık Sektöründe Bir Uygulama, İş, Gü̧ç Endüstri İlişsileri ve İnsan Kaynakları Dergisi, 17(2), 92-108.

Gardner, W. L., Avolio, B. J., Luthans, F., May, D. R., \& Walumbwa, F. (2005). "Can you see the real me?" A self-based model of authentic leader and follower development. The Leadership Quarterly, 16(3), 343-372.

Hannah, S. T., Lester, P. B., \& Vogelgesang, G. R. (2005). Moral leadership: Explicating the moral component of authentic leadership. Authentic leadership theory and practice: Origins, effects and development, 3, 43-81.

Hassan, A., \& Ahmed, F. (2011). Authentic leadership, trust and work engagement. International journal of human and social sciences, 6(3), 164-170.

Hult, G. T. M., \& Ferrell, O. C. (1997). Global organizational learning capacity in purchasing: Construct and measurement. Journal of Business Research, 40(2), 97-111.

Ilies, R., Morgeson, F. P., \& Nahrgang, J. D. (2005). Authentic leadership and eudaemonic well-being: Understanding leader-follower outcomes. The Leadership Quarterly, 16(3), 373-394.

Kernis, M. H. (2003). Toward a conceptualization of optimal self-esteem. Psychological inquiry, 14(1), $1-26$.

Luthans, F., \& Avolio, B. J. (2003). Authentic leadership: A positive development approach. Positive organizational behavior 241-258.

Macneil, C., (2001), The Supervisor as a Facilitator of Informal Learning in Work Teams, Journal of Workplace Learning, Vol. 13 Issue: 6, pp.246-253.

Marquardt, M. J. (1996). Building the learning organization: A systems approach to quantum improvement and global success. McGraw-Hill Companies.

Polston-Murdoch, L., (2015), Innovative Behavior in Local Government: Exploring The Impact of Organizational Learning Capacity, Authentic Leadership, Psychological Empowerment, And The Moderating Role of Intrinsic Motivation, Doctor of Philosophy, Regent University.

Schein, E. H. (1999). Empowerment, coercive persuasion and organizational learning: do they connect?. The Learning Organization, 6(4), 163-172.

Teo, H. H., Wang, X., Wei, K. K., Sia, C. L., \& Lee, M. K. (2006). Organizational learning capacity and attitude toward complex technological innovations: An empirical study. Journal of the Association for Information Science and Technology, 57(2), 264-279. 
Journal of Global Strategic Management | V. 12 | N. 1 | 2018-June | isma.info | 057-066 | DOI: 10.20460/JGSM.2018.261

Vera, D., \& Crossan, M. (2004). Strategic leadership and organizational learning. Academy of management review, 29(2), 222-240.

Walumbwa, F. O., Avolio, B. J., Gardner, W. L., Wernsing, T. S., \& Peterson, S. J. (2008). Authentic leadership: Development and validation of a theory-based measure. Journal of management, 34(1), 89126.

Wong, C. A., \& Cummings, G. G. (2009). The influence of authentic leadership behaviors on trust and work outcomes of health care staff. Journal of Leadership Studies, 3(2), 6-23. 